\title{
Business Performance Based on Specialized and Architecture Marketing Capabilities
}

\author{
Siti Sumiati ${ }^{1}$, Alifah Ratnawati ${ }^{2}$, Ahmad Suffian Mohd Zahari ${ }^{3}$, Nurul Ulfa Abdul Aziz ${ }^{4}$ \\ Faculty of Economics UNISSULA ${ }^{1,2}$ \\ Faculty of Business and Management UiTM Terengganu Malaysia ${ }^{3,4}$ \\ \{sitisumiati@unissula.ac.id ${ }^{1}$, alifah@unissula.ac.id ${ }^{2}$ \}
}

\begin{abstract}
This study aims to analyze and test the relationship between market orientation and SMEs business performance with the architectural marketing capabilities and specialized marketing capabilities as intervening variables. The study used 450 Muslim SMEs in Central Java as a research sample. The data analysis technique used in this study is Structural Equation Modeling (SEM) with AMOS Version 22.0. The results of the research hoped that the five hypotheses showed the results of a positive and significant effect between variables, meaning that all hypotheses in this study were accepted. The architectural marketing capabilities and specialized marketing capabilities hoped can improve SMEs business performance so that both variables are becoming intervening variables.
\end{abstract}

Keywords: Market Orientation, Specialized Marketing Capabilities, Architectural Marketing Capabilities, Smes Business Performance

\section{Introduction}

In the last three decades, there have been many studies focusing on the relationship between market orientation and business performance. Such studies, in general, have shown that market orientation is the key to success in creating a superior business performance (Lee et. al., 2015; Qu and Zhang, 2015; Takata, 2016). Market orientation was initially introduced as a reflective composite, and some researchers have investigated whether or how this single composite is related to other variables such as good business performance (Dong et. al., 2016). While many studies have surprisingly reported significant direct positive effects of market orientation on performance (Kirca et. al., 2005; Morgan et. al., 2009c; Qu and Zhang, 2015; Beneke et. al., 2016), which others revealed insignificant relationships (Langerak et. al., 2004; Huhtala et. al., 2014; Kajalo and Lindblom, 2015). This difference might suggest an unaddressed moderator, a defective or incorrect measurement tool, or a variety of data collection or analysis techniques. It is also possible that these conflicting findings result from the fact that fragmented market orientation components can be related to business performance in a unique way (Dong et. al., 2016).

In addition to the research gap above, up to now, there are still not many researchers who determine how market orientation contributes to superior business performance. Several studies have investigated potential mediators from the relationship between market orientation 
and business performance. Such research is needed to understand the route of market orientation in influencing business performance. As explained by Han et al. (1998), from a strategic point of view, market orientation remains incomplete if practitioners do not understand the modus operandi that results in superior business performance. By explaining the mediator of the relationship between market orientation and business performance, it will provide managers with more detailed insights on how market orientation works and how it can be useful as a strategic corporate capability. Therefore, this research tries to fill this knowledge gap by placing specialized marketing capabilities and architectural marketing capabilities as mediator in the relationship between market orientation and business performance.

Specialized marketing capabilities are a core element of marketing capabilities for three reasons. First, specialized marketing capabilities determine the effectiveness of marketing strategy decisions and marketing strategy implementation (Morgan, 2012; Morgan et. al., 2012). Second, specialized marketing capabilities determine superior business performance (Morgan et. al., 2009c). Specialized marketing capabilities are a source of company positional advantage (Morgan et. al., 2004). Fourth, the increasing level of competition, technological developments in the market and shorter product life cycles press the company to continue to increase its capacity in developing specialized marketing capabilities.

Recently, research on the impact of market orientation on specialized marketing capabilities has not yet been found. Sometimes market orientation and specialized marketing capability are treated as independent variables that affect company performance (Morgan et. al., 2009c). At this time, opportunities exist to advance understanding of the relationship between market orientation, specialized marketing capabilities, architectural marketing capabilities, and business performance. In this study, market orientation is understood as a set of organizational behavior and processes (i.e. a series of activities) related to market intelligence generation; market intelligence dissemination; and responsiveness to such intelligence across departments (Kohli and Jaworski, 1990; Carbonell and Rodríguez Escudero, 2010).

Based on the knowledge gap above, the problem found is that, "there is still limited knowledge that explains how the market orientation route affects the SMEs business performance". Therefore, this research problem can be formulated as: "How to build a new approach that can fill the research gap regarding the role of market orientation in improving company business performance?"

\section{Literature Review}

\subsection{Market Orientation}

Market orientation is a marketing management concept that facilitates a company's ability to provide superior products and services to internal and external customers (Lee et. al., 2015). From a behavioral perspective, market orientation emphasizes activities related to market intelligence generation, market intelligence dissemination, and responsiveness to market intelligence (Jaworski and Kohli, 1993). In this context, companies oriented to competitive advantage need to identify various customer needs, supplier needs, and competitor strategies; discuss information obtained; respond effectively to market changes; and diligently working to create products and services that will provide competitive advantage (Kohli and Jaworski, 1990). Research developments related to market orientation have suggested that market 
orientation must be investigated through a disaggregated approach (Carbonell and Rodríguez Escudero, 2010; Long et. al., 2017).

\subsection{Specialized Marketing Capabilities}

Specialized Marketing Capabilities concern specific functional-based processes used in organizations to combine and change resources (Vorhies and Morgan, 2005). Specific marketing skills are usually seen as a process that includes tactical marketing programs that are usually needed to implement marketing strategies (Vorhies and Morgan, 2003). This capability is related to the classic marketing mix of activities related to products, prices, communication, and distribution, and also the ability to sell and market research (Hunt and Morgan, 1995; Morgan, 2012).

\subsection{Architectural Marketing Capabilities}

Architectural Marketing Capabilities are related to architectural capabilities that give effect to marketing capabilities specifically. The existence of architectural marketing capabilities is due to group performance that refers to performance improvements related to a more strategic marketing mix. This involves planning and specialized marketing capabilities. The relationship between architectural marketing capabilities and specialized marketing capabilities justifies the need to deepen understanding of the influence of dispersing activities between areas (companies) and the development of marketing strategic capabilities. Architectural marketing capabilities is an ability developed through experiential market-based learning, where sharing information and knowledge is very important.

\subsection{Business Performance}

According to Murphy et. al. (1996), there are eight dimensions commonly used by researchers to measure business performance, which are Growth, Profit, Size, Liquidity, Success/Failure, Market Share, efficiency and Leverage. Some researchers use the growth dimension as a proxy for business performance (Cho and Pucik, 2005; Zhou et. al., 2007; Morgan et. al., 2009a; Debicki, 2017). This dimension may be more accurate and accessible to small and medium enterprises (Wiklund and Shepherd, 2005). Based on a meta-analysis study, Stam et. al. (2014) SMEs performance can be explained through three dimensions, namely growth performance, profitability, and non-financial performance. The measure of growth consists of sales growth, profits, employment and market share. Profitability measures relate to accounting-based indicators such as return on assets (ROA), return on equity (ROE), and return on sales (ROS) as well as self-reported profitability assessments. Non-financial performance includes various indicators of operational effectiveness such as technical advantage, competitive ability, productivity, and export performance.

\subsection{Market Orientation and Business Performance}

Arguments supporting the positive relationship between market orientation and business performance are well documented in the marketing literature (Gruber-Muecke and Hofer, 2015; Lee et. al., 2015; Qu and Zhang, 2015). A meta-analysis study by Kirca et. al. (2005) gathers empirical findings from a broad market orientation literature, concluding that market orientation has a positive effect on organizational performance. Therefore, market orientation 
is very important for the success of SME companies. In this context, SMEs need to understand their customers and competitors while involving all functions in the development of new products that satisfy customer needs (Ledwith and O'Dwyer, 2008). In many empirical studies in this decade, market orientation has become an important antecedent of business performance. For example, Wei-Shong et. al. (2015) shows market orientation in the form of intelligence generation, intelligence dissemination, and responsiveness to intelligence, has a very strong influence on business performance. In this context, business performance referred to Market Knowledge Creation, Customer Satisfaction, and Profit Performance. Likewise, research by Lee et. al. (2015) shows the three dimensions of market orientation have a positive effect on financial performance and non-financial performance. These findings are consistent with some of the early studies in market orientation literature (Narver and Slater, 1990; Jaworski and Kohli, 1993). This is in line with the research of Jaworski and Kohli (1993) that market orientation is in the form of market intelligence generation, market intelligence dissemination and responsiveness to market intelligence, thus the $\mathrm{H} 1$ is proposed:

H1: There is a positive relationship between market orientation and business performance.

\subsection{Market Orientation and Architectural Marketing Capabilities}

Some previous research findings found a positive relationship between market orientation and architectural marketing capabilities (Kaleka and Morgan, 2017; Iyer et al., 2018; Lee et al., 2009; Gao et al., 2010; Morgan et al., 2004). Architectural marketing capabilities is a combination of knowledge and ability which becomes an important alternative way to increase competitors' advantage (Dalvi and Seifi, 2014). The existence of market orientation is one of the core capabilities of marketing dynamics and is a market-based asset (Barrales-Molina et al., 2014; Morgan et al., 2009). This supports the realization of marketing targets set by the company. The effort made is to make a strategy. One of them is by increasing architectural marketing capabilities, which is one form of Marketing Strategic Capabilities. This understanding is an activity that has several features of the core of marketing dynamic capabilities as well as the presence of dissemination mechanisms related to key markets (Barrales-Molina et al., 2014; Morgan et al., 2009). Therefore, H2 is proposed:

$\mathrm{H} 2$ : There is a positive relationship between market orientation and architectural marketing capabilities.

\subsection{Market Orientation and Specialized Marketing Capabilities}

Research conducted by (Lee et. al., 2015) explores the role of market orientation towards business performance in the context of franchising, it seems that the market orientation facilitates the company's business strategy that positively influences its business performance. These findings broaden the existing literature by studying the relationship of market orientation with a business performance by emphasizing business strategies with differentiation and cost advantage. This study tries to enrich knowledge about the relationship between market orientation and business performance by placing specialized marketing capability as a mediating variable. Companies with a solid market orientation will be more dynamic in finding opportunities and more able to identify and take advantage of opportunities that arise in external markets than companies that do not have this ability. In this context, companies that have the right information about their markets tend to be more willing to vary their marketing mix, sales strategies, and market research, rather than other companies that lack information and decide based on instinct (Navarro-García et. al., 2014). In other words, 
the behavior of marketing orientation is very valuable because it facilitates specialized marketing capabilities to achieve better business performance. Therefore, it is supported by research of Jaworski and Kohli (1993) that market orientation is in the form of market intelligence generation, market intelligence dissemination, and responsiveness to market intelligence. Furthermore, H3 is proposed:

H3: There is a positive relationship between market orientation and specialized marketing capability.

\subsection{Architectural Marketing Capabilities and Business Performance}

According to experts, architectural marketing capabilities is an ability that mixes knowledge with the ability (Ferdinand and Batu, 2013; Morgan et al., 2009). The business performance of a company is the main point of business survival. One effort to improve business performance is the influence of architectural marketing capabilities within the company. Some experts have previously conducted a test related to the relationship between architectural marketing capabilities and business performance. The results obtained suggest that there is a positive effect between architectural marketing capabilities and business performance (Ferdinand and Batu, 2013; Ortega and Villaverde, 2008; Conant, Mokwa, \& Varadarajan, 1990; Desarbo, Benedetto, Song, \& Singha, et al., 2005; Song et al., 2007). The positive effect of architectural marketing capabilities on business performance can maintain a sense of customer loyalty through marketing communications that are uniquely and attractively displayed (Ferdinand and Batu, 2013). Proposals related to marketing capabilities will have more impact on the performance of companies that invest in better assets. It aims to innovate in a more dynamic business environment (Ortega and Villaverde, 2008). Based on this explanation, the $\mathrm{H} 4$ is proposed as follows:

H4: There is a positive relationship between architectural marketing capabilities and SMEs business performance.

\subsection{Specialized Marketing Capabilities and Business Performance}

Empirically, marketing capabilities such as what contributes to business performance have not yet been discovered. Very little is known about the relative contribution of various highlevel marketing capabilities to SMEs business performance (Merrilees et. al., 2011). Empirical studies that occur more focused on the general aspects and some individual elements of marketing capabilities on marketing performance. In general, the positive influence of marketing capabilities on business performance has been well documented (Morgan et. al., 2009c; Wu, 2013; Ahmed et. al., 2014; Kajalo and Lindblom, 2015). Meanwhile, several dimensions of marketing capabilities, such as market sensing capabilities (Day, 1994; Osakwe et. al., 2016), brand management capabilities (Osakwe et. al., 2016), and CRM capabilities (Wang and Feng, 2012) are important variables that affect business performance. Finally, the potential relationship between specialized marketing capabilities and business performance is very possible considering that superior business performance arguments are only possible when a company has specialized marketing capabilities such as the ability to manage the marketing mix, and also sales and market research. Thus, the H5 is proposed:

H5: There is a positive relationship between specialized marketing capabilities and SMEs business performance. 


\section{Methodology}

This research is a scientific exploration that includes basic research categories. The fundamental purpose of this research is to develop knowledge to look for new answers to management problems that occur in organizations, companies, and communities (Ferdinand, 2013). The object of research chosen in this study is micro, small and medium enterprises (SMEs) in Central Java so that the population in this study include business owners, business managers, or owners who are also business managers whose numbers have not been known with certainty up to now. The sample of this study are SMEs from 10 regencies/cities in Central Java, which are from Semarang, Demak, Jepara, Kudus, Grobogan, Rembang, Pekalongan, Batang, Kendal, Surakarta. In 10 districts/cities, the 450 questionnaires were distributed within 2 months from May 2019 to July 2019.

Because the number of population is not known with certainty, then the method of sampling is done by non-probability sampling. The snowball sampling technique is used to trace the position of prospective research respondents. This study took SMEs as sample by using a purposive sampling method with criteria, (1) respondents already have at least 3 years experience because they are considered to have business experience and know the development of company performance, (2) have annual sales results of at most $\mathrm{Rp}$ $50,000,000,000$, ( 3 ) do not have above 100 employees, and (4) are willing to provide information.

The data needed in this study are primary and secondary data. Primary data were obtained directly from research respondents namely from the owner, manager or owner who is also the manager of SMEs in Central Java. Secondary data is data obtained not directly from respondents but related to research objects, such as data obtained from documentation, literature relating to research problems and from other sources such as Central Bureau of Statistics (BPS) of Central Java Province and Ministry of Industry and Trade (Disperindag) of Central Java Province.

Measurement of each instrument used an interval scale of 1 to 10, a score of 1 indicates strongly disagree on a statement given and a score of 10 indicates strongly agree. Instruments for each variable will be explained in table 2 . The data analysis technique used in this study is Structural Equation Modeling (SEM) with AMOS Version 22.0. This technique is usually used to test a series of relatively complex relationships/models such as those in marketing research and strategic management (Ferdinand, 2013).

This study used three dimensions of market orientation variable, which are market intelligence generation, market intelligence dissemination, responsiveness to market intelligence; specialized marketing capabilities and business performance. The operational definition of these variables is obtained from various views of previous researchers. The operational definitions, indicators, and instruments used to analyze the research model are explained in Table 1:

Table 1. Operational Definitions, Measurements and Indicators

\begin{tabular}{|c|c|c|c|}
\hline Operational Definition & Symbol & Indicator & Source \\
\hline \multirow{6}{*}{$\begin{array}{l}\text { Market Orientation is a } \\
\text { marketing management concept } \\
\text { that facilitates the ability to } \\
\text { provide superior products and } \\
\text { services to internal and external } \\
\text { customers. }\end{array}$} & MO1 & Continuity in meeting customers & Kohli et. al. \\
\hline & $\mathrm{MO} 2$ & Continuity in customer interactions & $(1993)$ \\
\hline & MO3 & Continuity in discussing competitors' strategies & \\
\hline & MO4 & Continuity in discussing market developments & \\
\hline & MO5 & Continuity in responding to changes in & \\
\hline & MO6 & $\begin{array}{l}\text { Continuity to pay attention to changes in } \\
\text { product needs or customer service. }\end{array}$ & \\
\hline
\end{tabular}




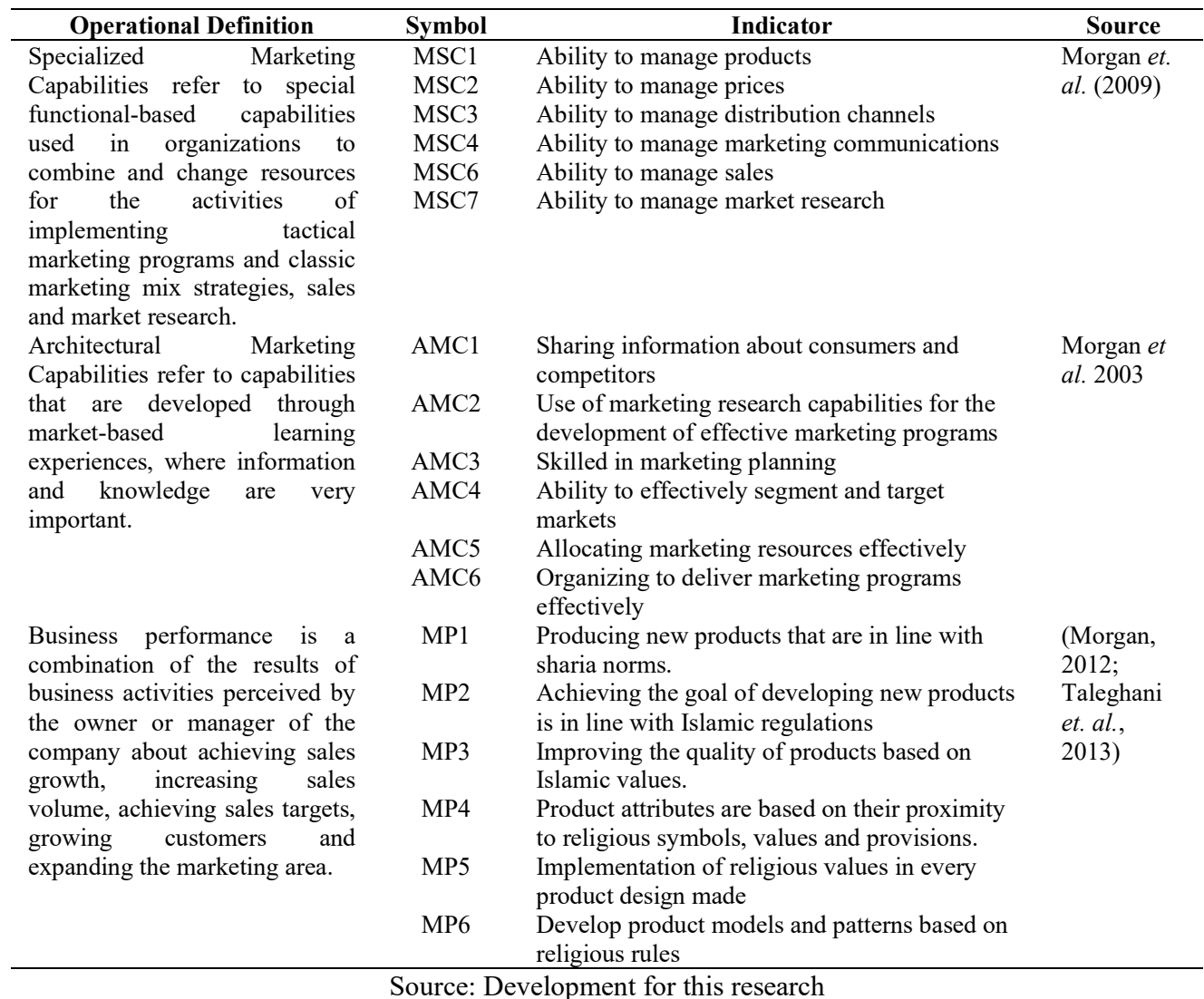

Source: Development for this research

The empirical test design model for the relationship between variables is explained in Figure 3.1.

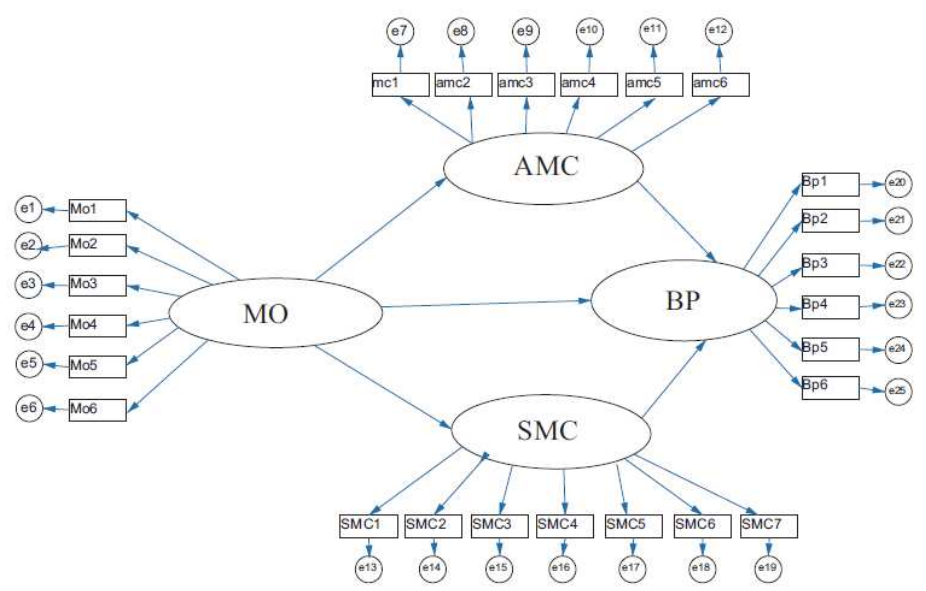

Source: Empirical research results for the research development, 2019

Fig. 1. Design of empirical testing of the relationship between MO, AMC, SMC and BP 


\section{Expected Results}

This research is expected to explain the relationship between the four variables, which are market orientation, architectural marketing capabilities, specialized marketing capabilities, and business performance of SMEs are also able to demonstrate the role of architectural marketing capabilities and specialized marketing capabilities as intermediary variables between market orientation and business performance. This paper only explains the role of one component of marketing capability, namely the existence of architectural marketing capabilities and specialized marketing capabilities in the relationship between market orientation and business performance.

\section{References}

[1] Ahmed, M. U., M. M. Kristal and M. Pagell (2014). "Impact of operational and marketing capabilities on firm performance: Evidence from economic growth and downturns". International Journal of Production Economics. 154. 59-71.

[2] Beneke, J., S. Blampied, N. Dewar and L. Soriano (2016). "The impact of market orientation and learning orientation on organisational performance: A study of small to medium-sized enterprises in Cape Town, South Africa". Journal of Research in Marketing and Entrepreneurship. 18. 1. 90-108.

[3] Carbonell, P. and A. I. Rodríguez Escudero (2010). "The effect of market orientation on innovation speed and new product performance". Journal of Business \& Industrial Marketing. 25. 7. 501-513.

[4] Chakrabarty, S., R. E. Widing and G. Brown (2014). "Selling behaviours and sales performance: the moderating and mediating effects of interpersonal mentalizing". Journal of Personal Selling \& Sales Management. 34. 2. 112-122.

[5] Cho, H.-J. and V. Pucik (2005). "Relationship between innovativeness, quality, growth, profitability, and market value". Strategic Management Journal. 26. 6. 555575.

[6] Day, G. S. (1994). "The Capabilities of Market-Driven Organizations". Journal of Marketing. 58. 4. 37.

[7] Debicki, B. J. (2017). "Socioemotional Wealth and Family Firm Performance: A Stakeholder Approach". JOURNAL OF MANAGERIAL ISSUES. Vol. XXIX. Number 1. pp. 82-111.

[8] Dong, X., Z. Zhang, C. A. Hinsch and S. Zou (2016). "Reconceptualizing the elements of market orientation: A process-based view". Industrial Marketing Management. 56. 130-142.

[9] Ferdinand, A. (2013). "Metoda Penelitian Manajemen : Pedoman Penelitian untuk Penulisan Skripsi, Tesis dan Disertasi Ilmu Manajemen". Edisi 4. Badan Penerbit Universitas Diponegoro. Semarang.

[10] Ghozali, I. (2011). "Model Persamaan Struktural : Konsep \& Aplikasi dengan Program AMOS 19.0". Edisi IV. Badan Penerbit Universitas Dipenegoro. Semarang.

[11] Gruber-Muecke, T. and K. M. Hofer (2015). "Market orientation, entrepreneurial orientation and performance in emerging markets". International Journal of Emerging Markets. 10. 3. 560-571.

[12] Hair, J. F., W. C. Black, B. J. Babin and R. E. Anderson (2010). Multivariate Data Analysis 7th Edition, Pearson Prentice Hall. 
[13] Huhtala, J.-P., A. Sihvonen, J. Frösén, M. Jaakkola and H. Tikkanen (2014). "Market orientation, innovation capability and business performance: Insights from the global financial crisis". Baltic Journal of Management. 9. 2. 134-152.

[14] Hunt, S. D. and R. M. Morgan (1995). "The comparative advantage theory of competition". The Journal of Marketing. 1-15.

[15] Jaworski, B. J. and A. K. Kohli (1993). "Market Orientation Antecedents and Consequences". Journal of Marketing. 57. 3. 53.

[16] Kajalo, S. and A. Lindblom (2015). "Market orientation, entrepreneurial orientation and business performance among small retailers". International Journal of Retail \& Distribution Management. 43. 7. 580-596.

[17] Kirca, A. H., S. Jayachandran and W. O. Bearden (2005). "Market Orientation: A Meta-Analytic Review and Assessment of its Antecedents and Impact on Performance". Journal of Marketing. 69. 2. 24-41.

[18] Kohli, A. K. and B. J. Jaworski (1990). "Market orientation: the construct, research propositions, and managerial implications". The Journal of Marketing. 1-18.

[19] Kohli, A. K., B. J. Jaworski and A. Kumar (1993). "MARKOR: A measure of market orientation". JMR, Journal of Marketing Research. 30. 4. 467.

[20] Lambe, C. J. L., K. L. Webb and C. Ishida (2009). "Self-managing selling teams and team performance: The complementary roles of empowerment and control". Industrial Marketing Management. 38. 12.

[21] Lane Keller, K. (2001). "Mastering the Marketing Communications Mix: Micro and Macro Perspectives on Integrated Marketing Communication Programs". Journal of Marketing Management. 17. 7-8. 819-847.

[22] Langerak, F., E. J. Hultink and H. S. J. Robben (2004). "The Impact of Market Orientation, Product Advantage, and Launch Proficiency on New Product Performance and Organizational Performance". The Journal of Product Innovation Management. Vol. 21. pp. 79-94.

[23] Ledwith, A. and M. O'Dwyer (2008). "Product launch, product advantage and market orientation in SMEs". Journal of Small Business and Enterprise Development. 15. 1. 96-110.

[24] Lee, Y.-K., S.-H. Kim, M.-K. Seo and S. K. Hight (2015). "Market orientation and business performance: Evidence from franchising industry". International Journal of Hospitality Management. 44. 28-37.

[25] Long, Z., K. Ali, E. S. John and M.-W. Alma (2017). "Exploring market orientation among Chinese small and medium-sized enterprises". Chinese Management Studies. 11. 4. 617-636.

[26] Marn, M. V. and R. L. Rosiello (1992). "Managing Price, Gaining Profit". Harvard Business Review. Sept-Oct., 84-94.

[27] Matsuno, K. and J. T. Mentzer (2000). "The Effects of Strategy Type on the Market Orientation-Performance Relationship". Journal of Marketing. 64. 4. 1-16.

[28] Merrilees, B., S. Rundle-Thiele and A. Lye (2011). "Marketing capabilities: Antecedents and implications for B2B SME performance". Industrial Marketing Management. 40. 3. 368-375.

[29] Moorman, C. (1995). "Organizational Market Information Processes: Cultural Antecedents and New Product Outcomes". Journal of Marketing Research. Vol. 32. No. 3 (Aug. 1995). pp. 318-335.

[30] Morgan, N. A. (2012). "Marketing and business performance". Journal of the Academy of Marketing Science. 40. 1. 102-119. 
[31] Morgan, N. A., A. Kaleka and C. S. Katsikeas (2004). "Antecedents of Export Venture Performance: A Theoretical Model and Empirical Assessment". Journal of Marketing. 68. 1. 90-108.

[32] Morgan, N. A., C. S. Katsikeas and D. W. Vorhies (2012). "Export marketing strategy implementation, export marketing capabilities, and export venture performance". Journal of the Academy of Marketing Science. 40. 2. 271-289.

[33] Morgan, N. A., R. J. Slotegraaf and D. W. Vorhies (2009a). "Linking marketing capabilities with profit growth". Intern. J. of Research in Marketing. 26 (2009). pp. 284-293.

[34] Morgan, N. A., R. J. Slotegraaf and D. W. Vorhies (2009b). "Linking marketing capabilities with profit growth". International Journal of Research in Marketing. 26. 4. 284-293.

[35] Morgan, N. A., D. W. Vorhies and C. H. Mason (2009c). "Market orientation, marketing capabilities, and firm performance". Strategic Management Journal. 30. 8. 909-920.

[36] Murphy, G. B., J. W. Trailer and R. C. Hill (1996). "Measuring Performance in Entrepreneurship Research". Journal of Business Research. Vol. 36 pp. 15-23.

[37] Narver, J. C. and S. F. Slater (1990). "The effect of a market orientation on business profitability". The Journal of Marketing. 20-35.

[38] Navarro-García, A., J. Arenas-Gaitán and F. J. Rondán-Cataluña (2014). "External environment and the moderating role of export market orientation". Journal of Business Research. 67. 5. 740-745.

[39] Osakwe, C. N., M. Chovancova and B. U. Ogbonna (2016). "Linking SMEs Profitability to Brand Orientation and Market-Sensing Capability: A Service Sector Evidence". Periodica Polytechnica Social and Management Sciences. 24. 1. 34-40.

[40] Qu, R. and Z. Zhang (2015). "Market orientation and business performance in MNC foreign subsidiaries- Moderating effects of integration and responsiveness". Journal of Business Research. 68. 5. 919-924.

[41] Schmitz, C. (2012). "Group influences of selling teams on industrial salespeople's cross-selling behavior". Journal of the Academy of Marketing Science. 41. 1. 55-72.

[42] Stam, W., S. Arzlanian and T. Elfring (2014). "Social capital of entrepreneurs and small firm performance: A meta-analysis of contextual and methodological moderators". Journal of Business Venturing. 29. 1. 152-173.

[43] Takata, H. (2016). "Effects of industry forces, market orientation, and marketing capabilities on business performance: An empirical analysis of Japanese manufacturers from 2009 to 2011". Journal of Business Research.

[44] Taleghani, M., S. Gilaninia and S. Matloub Talab (2013). "Relationship between Market Orientation Culture and Business Performance". INTERDISCIPLINARY JOURNAL OF CONTEMPORARY RESEARCH IN BUSINESS. 5. 01. 949-954.

[45] Tarute, A. and R. Gatautis (2014). "ICT Impact on SMEs Performance". Procedia Social and Behavioral Sciences. 00. pp. 1-8.

[46] Trez, G., J. Camra-Fierro and F. Bins Luce (2012). "Organizational structure and specialized marketing capabilitie in SMEs". Marketing Intelligence \& Planning. 30. 2. 143-164.

[47] Vorhies, D. and N. Morgan (2005). Benchmarking Marketing Capabilities for Sustainable Competitive Advantage. 
[48] Vorhies, D. W. and N. A. Morgan (2003). "A Configuration Theory Assessrnent of Marketing Organization Fit with Business Strategy and its Relationship with Marketing Performance". Journal of Marketing. Vol. 67 (January 2003). pp. 100-115.

[49] Wang, Y. and H. Feng (2012). "Customer relationship management capabilities. Measurement, antecedents and consequences". Management Decision. 50. 1. 115-129.

[50] Wei-Shong, L., H. Jing-Wen and Y. Ming-Yih (2015). "Developing the capability of marketing intelligence: A subjective dynamic capability study". Benchmarking: An International Journal. 22. 7. 1341-1359.

[51] Wei, Y. and Q. Wang (2011). "Making sense of a market information system for superior performance: The roles of organizational responsiveness and innovation strategy". Industrial Marketing Management. 40. 2. 267-277.

[52] Weitz, B. A. and S. O. Jap (1995). "Relationship Marketing and Distribution Channels". Journal of the Academy of Marketing Science. Volume 23. No. 4. pp. 305320 .

[53] Wiklund, J. and D. Shepherd (2005). "Entrepreneurial orientation and small business performance: a configurational approach". Journal of Business Venturing. 20. 1. 7191.

[54] Wu, J. (2013). "Marketing capabilities, institutional development, and the performance of emerging market firms: A multinational study". International Journal of Research in Marketing. 30. 1. 36-45.

[55] Zhou, L., W.-p. Wu and X. Luo (2007). "Internationalization and the performance of born-global SMEs: the mediating role of social networks". Journal of International Business Studies. 38. 4. 673-690. 